\title{
Digital literacies in in-service and pre-service teacher education: some considerations on the learning provided by such process
}

O presente trabalho foi realizado com apoio do CNPq, Conselho Nacional de Desenvolvimento Científico e Tecnológico - Brasil.

\section{Ana Karina de Oliveira Nascimento}

Doutoranda em Estudos Linguísticos e Literários em Inglês na Universidade de São Paulo; Bolsista CNPq; Professora do Departamento de Letras Estrangeiras da UFS - Universidade Federal de Sergipe; Aracaju; Sergipe; Brasil; akcoliveira@gmail.com

Abstract: This paper aims at discussing continuing and pre-service teacher education, when it comes to teachers' everyday practices that involve digital literacies, as defined by Lankshear and Knobel (2008). It is a qualitative-interpretative analysis, a result of data collected through questionnaires, interviews and class recordings during an inservice teacher education project but which focuses on the questionnaires answered by undergraduate English students from a federal university in Brazil working on the same group. The results point to the fact that it is beneficial providing pre-service education connected to in-service experiences, when the focus is on digital literacies.

Key words: teacher education; digital literacies; English
Resumo: Esse trabalho objetiva discutir formação continuada e inicial de professores no que concerne às práticas diárias docentes que envolvem letramentos digitais, conforme definição de Lankshear e Knobel (2008). Trata-se de uma análise qualitativa e interpretativa, resultante de dados coletados através de questionários, entrevistas e gravações de aula durante um projeto de formação continuada, mas que foca nos questionários respondidos por estudantes de graduação em Inglês de uma universidade federal brasileira, atuando no mesmo grupo. Os resultados apontam para o fato de que é benéfico promover experiências de formação inicial atreladas às de formação continuada, quando 0 foco está em letramentos digitais.

Palavras-chave: formação de professores; letramentos digitais; Inglês 

Traditionally, in Brazil, in-service teacher education has taken place apart from experiences of preservice teacher education, as if they represented unique moments which are not interconnected. The main assumption of this text is the fact that both experiences can happen at the same space and time and that this choice is highly beneficial for both sides involved.

In this respect, however, even though many different aspects can be taken for analysis, the focus here will be on practices involving digital literacies, as defined by Lanshear and Knoble (2008). According to the authors, digital literacies can be understood as the different possibilities of reading and understanding the several aspects involved when the individual has access to the digital world.

\section{Getting to know this specific context of teacher education}

The experience of teacher education referred to throughout this paper was part of a national project held in Brazil named "New literacies and multiliteracies theories and practices: critical education and the teaching of languages in Brazilian Schools"1. As part of this national project, many public universities all over the country decided to join and thus gathered professors and undergraduate English students who would like to work together with teachers of public schools. In the case of our specific group, i.e., in our local project ${ }^{2}$, four (4) undergraduate English students took part and it is about the participation of three (3) of them, together with those involved in in-service teacher education that we are going to analyze their views concerning the learning provided by the experience, making use of a qualitativeinterpretative analysis.
${ }^{1}$ This Project was coordinated by Walkyria Monte Mór and Lynn Mario Trindade Menezes de Souza, both members of the Department of Modern Languages at Universidade de São Paulo. And it was also connected to the Project BrazilCanada Knowledge Exchange (BRCAKE), coordinated by Prof.

Dr. Diana Brydon, Canada Research Chair in Globalization and Cultural Studies at the University of Manitoba, from which I have received funding in order to present results related to the study presented in this article at the Canadian Congress in 2014.

${ }^{2}$ The local Project, held at Universidade Federal de Sergipe was coordinated by prof. Vanderlei José Zacchi, and it was developed in the institution from 2010 to 2012. The project was funded by $\mathrm{CNPq}$ - the National Council of Scientific and Technological Development in Brazil, project n. 401394/20107 , to which we are thankful. 
When it comes to the teachers of public schools, part of the local project, we initially contacted twenty (20) individuals, who voluntarily answered an initial questionnaire, which served as a first contact with them and gave us a chance to know a little bit about them: professional experience, beliefs, practices. They were from different but all public schools of the Brazilian state where the research took place. Out of twenty, only twelve demonstrated some interest in taking part, and these were interviewed by the professors involved, who were always accompanied by an English undergraduate student. The local project took place during two years, from 2010 to 2012. During this period, a discussion group was created and we had scheduled meetings to discuss theoretical and practical issues involved in the teaching and learning of the English language in our state. The issues discussed emerged from the experiences we were having with the teachers and teachers-to-be who were always present and had a close contact with the project.

During the project, classes were also video recorded by our undergraduate students who had one more chance to view the experiences close to reality. These classes were recorded in two different moments. The first time the teacher chose a group and prepared a class which we were allowed to record and the second, months after the first experience, we sat together: undergraduate students, teachers and professors and prepared a class based on the issues we had been debating. By this time of the last recording, we had a total number of five (5) teachers voluntarily participating.

\section{Understanding digital literacies}

It is common to find in the literature concerning the use of technology in education too much enthusiasm concerning the idea that its use will certainly bring 
extraordinary results on the teaching and learning process (BROWN; WARSCHAUER, 2006; VALENTE, 1999, for example). In this paper, however, the main arguments go beyond that understanding and hope to contribute to clearing up some common misconceptions concerning the use of technology in education so that a fruitful discussion can take place. Thus, this is the path chosen due to two main reasons. First because there has always been a gap on the understanding of 'getting information' and 'assessing information', as well as 'seeking information' and 'coming to know something', as pointed out by Lankshear et al (1997); second because it has been common to treat 'education' and the 'pursuit of information' as synonymous.

The idea, thus, is that even though we do think the use of technology can help improve students' learning, this is something that needs to be approached with caution and understanding. After all, it is not the use of technology per se that might bring about positive effects on students' learning. Therefore, we teachers who take a stand on using technological tools in the classroom have to ensure that education is central and that technologies, new or old, must remain faithfully in the service of our main goal: educating people.

It is in this context that the discussion on what digital literacies are becomes central. The first thing to take into account is the fact that treating digital literacy in the plural form is an emerging trend, which is still marginal in the literature on the subject, but should be adopted because of:

the sheer diversity of specific accounts of "digital literacies" that exist, and consequent implications of that for digital literacy policies; the strength and usefulness of a sociocultural perspective on literacy as practice, according to which literacy is best understood as literacies [...]. By extension, 
then, digital literacy can usefully be understood as digital literacies - in the plural; the benefits that may accrue from adopting an expansive view of digital literacies and their significance for educational learning (LANKSHEAR; KNOBEL, 2008, p.2).

Following the tendency on the use of the term digital literacies in the plural form, it is important to point out the fact that there is a range of concepts available on what accounts for digital literacies. The concepts, however, belong to two different groups of ideas: those that view digital literacies as involving a list of specific skills and techniques considered necessary for qualifying an individual as literate and those that understand being digitally literate as mastering ideas and carefully evaluating, analyzing and synthesizing information. Thus, a broad line when it comes to conceptualizing digital literacies refers to the inconsistency between understanding it as mainly being able to perform technical skills and conceiving it as taking into account the cognitive, social and emotional aspects which take place when work takes place in the digital environment (BAWDEN, 2008).

Likewise, definitions can be differentiated taking into consideration the conceptual versus the standardized operational definition of digital literacies. Conceptual definitions view digital literacies as a general idea or ideal. Here, the view of multimodality as the capacity of mixing and understanding the mixed nature of messages is taken into account as being central to enable people to understand and be understood. As indicated by Cope and Kalantzis (2000), "[...] meaning is made in ways that are increasingly multimodal - in which written-linguistic modes of meaning are part and parcel of visual, audio and spatial patterns of meaning". On the other hand, standardized operational definitions do not take meaning- 
making into consideration. In fact, they relate to specific demonstration of skills, and view these as standard for general adoption (LANKSHEAR; KNOBEL, 2008).

The view we decide to adopt as to what digital literacies is relates to a broader definition, to the joint of what most authors see as opposing definitions, which is related to the idea of literacies as social practice. After all, we defend that the integration of digital technologies into learning, as mentioned earlier, must serve educational purposes. And as such, practices based on the development of digital literacies should "enable learners to become proficient with what we call the 'operational', 'cultural' and 'critical' dimensions of literacy and technology” (LANSKSHEAR, SNYDER, GREEN, 2000, p.xvii). Therefore, instead of adopting one of the two contrasting big definitions mentioned earlier, we are in favor of considering both ends of the continuum, since instead of contradicting, we see them as complementary. After all:

From a sociocultural perspective, [the] different ways of reading and writing and the "enculturations" that lead to becoming proficient in them are literacies. Engaging in these situated practices where we make meanings by relating texts to larger ways of doing and being is engaging in literacy - or, more accurately, literacies, since we are all apprenticed to more than one. To grasp this point is to grasp the importance of understanding that "digital literacy" must also be seen as digital literacies. Hence, when we take an expansive conception of "digital literacy", [...] we can see that "the ability to understand and use information in multiple formats from a wide range of sources when it is presented via computers" will take diverse forms according to the many and varied social practices out of which different individuals are enabled to understand and use information and communications (LANKSHEAR; KNOBEL, 2008, p.7). 
The point here then is to consider that the different possibilities of meaning-making and learning opportunities provided by the use of digital technologies in schools should go along the literacy project adopted by the institutions. It is in no way about transferring the same practices to a new medium. It is concerned about integrating technology into appropriate curriculum and pedagogical practice so as to provide students with one more chance to enhance their learning. It means to consider that:

As far as schooling is concerned, print is just one medium of literate practice within an entire range of available media. And the centre of gravity is shifting $[. .$.$] from Print to Digital-Electronics$ as the organizing context for literate-textual practice and for learning and teaching. [...] While this does not mean the end of print - the death of the book - it certainly means that teachers need to adopt a more flexible and expansive view of literacy than they have needed to date in their everyday lives and work (LANKSHEAR; SNYDER; GREEN, 2000, p.26).

Considering these points when the discussion is centered on continuing teacher education, it also involves giving teachers-to-be a chance to visualize that their teaching choices are a result of ideias shared by themselves which are, in most cases, a result of their own experiences as students and not really of informeddecision making, based on the reality of today's students. Therefore, attempts to give them a chance to not only sense how school work actually takes place when they incorporate their role of teachers, but also to connect theory learned during teacher education to real practice is a great chance to enhance their learning and consequently it might mean one step ahead of what teacher education can actually be when it comes to digital literacies. The next section is about such an experience. 


\section{Pre-service and in-service teacher education together: an experience}

As pointed out in the beginning of this paper, different techniques of data collection were used throughout the research project on new literacies theories involving continuing and pre-service teacher education which resulted in this text. With respect to continuing education, questionnaires, interviews and class recording were used as a way to enhance research possibilities and generate enough data so that the project could develop according to the data being gathered; after all, even though we knew the theory which was basic to our view of the teaching and learning process, we wanted to plan and execute our actions according to what teachers would let us see emerging from their practices.

Along the two years during which the project was being developed, four undergraduate English students also took part in all the activities proposed during data collection, study group and classroom preparation. It is on the participation of those students that we are about to focus, analyzing their views concerning working together with continuing teacher education, especially when it comes to the understanding and use of digital literacies. It is important to make clear that the data generated by these students, and analyzed here, were made available through a questionnaire applied to them after the end of the project, when they had just graduated. And it is based on answers given by 3 of them, since one of the students decided not to participate in this final task.

As also mentioned previously, the project was based on the new literacies studies and focused on three main topics: critical literacies, multimodality and digital literacies. For practical reasons, the researchers participating, even though working on the main topic - new literacies - had the chance to expand a bit more on one of the three specific ones stated above. Since I 
had been studying the topic before, I was responsible for working on specific issues related to digital literacies when dealing with the teachers and teachers-to-be.

In order to find out what had been most relevant to those students participating, the first question directed to them was about what students remembered from the project. The following answers were given:

Ed: "I remember that it was a very complex project, once several things had to be done $[. .$.$] :$ we had to read lots of texts, to attend several meetings, to discuss a lot, to plan every step that we were supposed to make; and (the best part of it) to travel to some places in order to record the teachers' classes".

Ana: "I remember I could study some academic materials about literacy, new literacies, multimodality $[\ldots]$ and some related texts. I used to meet some English teachers of public schools $[\ldots]$ and discuss some of these texts with them and the professors of my university to know about their routines in the schools and how we (they) could improve the classes based on the theory of new literacies".

Kate: "Meetings took place in order to discuss the relevant research topics related to theories of new literacies. Interviews involving the teachers working on the project also took place. Their classes were also recorded, analyzed and after some class planning based on the new literacies theories, they were recorded again".

It is possible to notice, based on students' answers, the fact that they got involved in the project through different activities, as well as the fact that we were all working together, learning from the process: teachersto-be, teachers and professors. It is worth noting what the student named Ana says concerning how we (they) could improve classes due to the participation in the 
project. Her answer, as well the ones given by the others, leaves the impression of a joint work being done, thus everybody learning from each other through sharing different perspectives and experiences.

Since they expressed they remembered how the project worked, they were then asked to describe their specific participation in it. The objective of this question was to try to understand how and if they related participation to their pre-service teacher education. The answers were:

Ed: "In certain way, I feel that I gave my contribution to the project. My duty was to read text materials related to Multimodalities and Multiliteracies and to discuss with my partners how they could be applied in the object of our studies: some in-service teachers of public schools $[\ldots]$ and their class environments."

Ana: "I started in the group because I was working on preliminary research on Critical Literacy with one of the professors of the university. I used to go to the meetings to discuss and give my own opinions (based on the theoretical material) [...]. I used to have some informal conversations with the teachers to really know about the class contexts they were involved in and their beliefs concerning teaching."

Kate: "Participating in the research project was very important to me since I could deepen my knowledge on new literacies, especially on digital literacies (topic of the small group I worked on). During the two years, I could learn as well as contribute with the project during discussions, presentations, interviews, recordings, transcriptions, etc."

As it is possible to observe from the answers, each of the three students participated in one of the three different topics worked on throughout the project: 
critical literacies, multimodality and digital literacies. It is important to note that they make clear that they felt they were collaborating with the project and learning from it, and one of them explicitly mentioned learning though they all give this idea of a giving and taking exchange of knowledge.

It is also interesting to point out the fact that we, the heads of the project, were not worried about pointing out what students were learning from the experience. We let them free to feel it as they were doing their best to accomplish the demands of the project, which were many, as mentioned in the answers given right above. This did not mean, however, we could not raise students' awareness when there was an opportunity. On the contrary. This was a possibility depending on what students' were experiencing.

This is, in fact, connected to what Pennycook (2004) calls critical moments. According to the author, who focuses on pre-service teacher practice (practicum) and defends the importance of working on this practice connected with theory so that this practicum might become praxicum (practicum together with praxis), it is important in order to have critical teachers, to take advantage of critical moments, which make possible to raise questions of power and authority, providing students (teachers-to-be) with a chance to discuss and critically reflect upon reality, thus widening the possibilities of social change.

Following his argumentation of working through critical moments in teacher education, Pennycook (in press, 2004, p.6-7) calls attention to the fact that:

learning to teach is not just about learning a body of knowledge and techniques; it is also about learning to work in a complex sociopolitical and cultural political space $[\ldots]$ and negotiating 
ways of doing this with our past histories, fears and desires; our own knowledges and cultures; our students' wishes and preferences; and the institutional constraints and collaborations.

Following the author's arguments, then, being part of the project was beneficial to the students, teachersto-be, as they had the chance to deal with and work on other issues rather than the ones normally dealt with in the academy. Besides, having contact with a specific body of knowledge, students also had the chance to critically emerge in the everyday practices of public schools and their teachers.

The next question students were asked to answer was about pointing out the issues related to digital literacies which had been worked on during the project and what they had learned from the experience:

Ed: "It would be very difficult to remember everything. However, I can remember that we discussed texts related to the effects of globalization on the digital world; the use of technology as means of empowerment; connectedness between local realities and other ones, forming networks of cultural, social and (why not) political knowledge. Still, analyzing all the points studied I could understand that guiding people to be more aware of the power of such digital world, they would not only have an important tool in their hands to empower themselves, but also to do it with everyone else, like those in their own community. Yet, individuals could also understand that everything that is on the virtual world is not displayed randomly, e.g., on their computer screens, but they may have an objective: perhaps to inform or even persuade them".

Ana: "We (the group) read and discussed texts about New Literacies that also included Digital Literacy contents. We worked on this through some activities. For example, when we went to 
a public school to have a class in the computer laboratory. We had a workshop on how to use blogs. We thought about starting with the teachers, because most of them were not updated in the use of the internet. This was possible because we realized they just use the internet to download songs and take some printable activities to class. They did not use it to teach students about some websites that they (students) could access to find information about what they were learning at school, or even social networks for school purposes".

Kate: "It was discussed that digital literacy is not only about knowing how to use the computer or any other digital tool, i.e. not only technical skills. It is crucial to make the best use the tools offer, according to what interests the one who is using them. Also, it is important to notice that in the virtual world of the internet, it is necessary to select relevant information and know if the sources are reliable [...]. I see digital literacy as critical literacy put into practice through and for digital tools. Realizing how to work on digital literacy in a class was extremely important to me. The project was very interesting because it allowed us to see the theoretical discussions together with the practical ones, and that is exactly what in-service teachers and teachers-tobe need to improve".

It is possible to see that the view of digital literacies developed throughout the project, as pointed out by the students above, involve what has been explained in the former section: the operational together with the conceptual view of digital literacies. Besides, they all make clear the fact that the concept dealt with relates to understanding the digital practices as socially constructed, therefore not neutral. Thus, as something to which teachers' attention should be called so as to develop students' awareness as to the use of digital tools, either at school or in their everyday life beyond educational purposes. 
It was also interesting to note the fact that they associate the development of digital literacies to the fundamental ideas of critical literacies (CERVETTI; PARDALES; DAMICO, 2001), when considering developing activities in the classroom. As discussed by Morgan (2009), when he provides a relevant example on the use of digital media for the development of critical literacy within the subject of English for Academic Purposes (EAP) he taught at the university, by proposing a different writing of an essay as a final paper, the idea was to use the internet in order to provide students with a chance to critically reflect upon the media coverage of a social topic. According to the author, and this is what we tried to develop throughout the project, the internet can be a very useful source since it allows the interaction with different views from diverse sources, other than the mainstream. In fact, he states: "In a highly restricted marketplace - where ownership of information systems is concentrated - digital technologies such as the internet are particularly suited for critical inquiry, providing access to diverse voices marginalised by mainstream media [...]" (MORGAN, 2009, p.319). On the other hand, the same author warns readers to the fact that "[...] the nature of this content lends itself to internet use, but the use of the internet does not guarantee critical engagement" (p.320). Here we see the importance of developing practices based on digital literacies. And it is based on this concern that students were asked if they took the discussion on digital literacies into account when preparing their classes now that they are teachers. The answers given were:

Ed: "I could say "a little bit", but, in fact, I do not feel that I am working such point at my job. Because, unfortunately, I have not had the chance to teach in regular schools and I am currently working as a teacher in a language school with its own methodology and steps to follow. Then, 
I cannot say that I take digital literacies into account while preparing my classes because everything is already prepared there".

Ana: "I learned that I can prepare lesson plans $[\ldots]$ and contextualize it with some activities on the internet. For example, I can ask them to do activities on Facebook or whatsapp. Or work with authentic texts and compare them with unauthentic ones and discuss it. I also learned how to find materials to add to the activities from the book like cartoons or games. This way I can make the class make sense to students and they learn through those other possibilities".

Kate: "Whenever it is possible, I raise questions so that students can reflect upon and discuss in English, but connected to the grammar issue being studied, since there is time constraint and I do not have much freedom to prepare different classes other than the ones proposed by the English school (private school). I feel that in this respect, public schools give teachers more freedom.

The students' accounts go on the direction of expressing institutional issues which can be determinant as to the teachers' decisions on what to do in the classroom. Two of them state the fact that classes are prepared following specific demands imposed by private schools and that they believe if they were in public schools they could do things differently. That makes me believe that this view was due to their participation in the project; after all, they had the chance to closely connect to public schools and their teachers the time the project was taking place.

One of the students, however, who does not make clear where she has been working, states that she can make use of digital tools in order to find extra materials, such as cartoons, which she can add to the book so that teaching can make more sense to students. This was a very 
interesting account, since it is based on understanding students' background knowledge and acting on it as part of what Gee (2004) calls situated language practice, one of the topics discussed throughout the project, which, when it comes to language, relates to the idea that "If any variety of language is to be learned and used, it has to be situated. That is, it has to be brought down to concrete exemplifications in experiences learners have had". And this is what the concept of digital literacies adopted here is about: not only technically using the digital tools available but also being able to question the uses, both at school and outside of it.

\section{Final remarks}

The main objective of this paper was to discuss continuing and pre-service teacher education connected to practices that involved digital literacies. The data collected via questionnaires answered by undergraduate English students were then analyzed through a qualitative-interpretative analysis.

It was possible to note that even though in Brazil, in-service teacher education has traditionally taken place apart from experiences of pre-service teacher education, the analysis demonstrated that both experiences can happen at the same space and time and that this choice is fruitful for both sides involved, at least when the focus was on digital literacies. After all, students' responses pointed to important issues which need to be taken into account, such as: dealing with the digital world differs from other activities; no use of digital tools is neutral; it is crucial for teachers' work to have some freedom in order to do their job; and finally, the work involving continuing teacher education when taking place together with pre-service practices helps teachers-to-be to understand and open opportunities for them to become better professionals later. 


\section{Special thanks}

To the funding received from the Project BrazilCanada Knowledge Exchange (BRCAKE), coordinated by Prof. Dr. Diana Brydon, Canada Research Chair in Globalization and Cultural Studies at the University of Manitoba. This project is a result of a research collaboration between Diana Brydon (Manitoba), Lynn Mario Menezes T. de Souza (USP) and Walkyria Monte Mor (USP). The last ones responsible for the National Project on teacher education, linked to the BRCAKE Project.

To the funding for the local project received by $\mathrm{CNPq}$, the National Council of Scientific and Technological Development in Brazil, project $n$. 4013942010-7, coordinated by prof. Vanderlei José Zacchi, to whom I am also thankful.

This paper was written with the support of CNPq, the National Council of Scientific and Technological Development - Brazil, due to the grant, which is part of my doctoral studies. 


\section{References}

BAWDEN, D. Origins and Concepts of Digital Literacy. In: LANKSHEAR, C.; KNOBEL, M. (ed.). Digital Literacies: concepts, policies and practices. New York: Peter Lang Publishing, 2008.

BROWN, D; WARSCHAUER, M. From the university to the elementary classroom: students' experiences in learning to integrate technology in instruction. Journal of Technology and Teacher Education, 14 (3), 2006. p.599-621.

CERVETTI, G.; PARDALES, M. J.; DAMICO, J. S. A tale of differences: comparing the traditions, perspectives and educational goals of critical reading and critical literacy. Reading Online, v. 4, n. 9, 2001. Disponível em: <http://www. readingonline.org/articles/art_index.asp?HREF=articles/ cervetti/index.html>. Access: 30 ${ }^{\text {th }}$ March 2010.

COPE, B; KALANTZIS, M. Multiliteracies: literacy learning and the design of social futures. Londres: Routledge, 2000.

GEE, J. P. Situated Language and Learning. New York and London: Routledge, 2004.

LANKSHEAR, C. et al. Digital Rhetorics: Literacies and Technologies in Education - Current Practices and Future Directions. Department of Employment, Education, Training and Youth Affairs. Canberra: Queensland University of Technology, 1997.

.; KNOBEL, M. (ed.). Digital Literacies: concepts, policies and practices. New York: Peter Lang Publishing, 2008.

.; SNYDER, I.; GREEN, B. Teachers and

Technoliteracy: Managing literacy, technology and learning in schools. St. Leonards: Allen and Unwin, 2000. 
MORGAN, B. Revitalizing the essay in an English for Academic Purposes program: Critical engagement, multiliteracies, and the Internet. International Journal of Bilingual Education and Bilingualism, 12(3), 2009. pp.309324.

PENNYCOOK, A. Critical Moments in a TESOL Praxicum. 2004. (in press).

VALENTE, J. A. (Org.). O computador na sociedade do conhecimento. Campinas, SP: UnicampNIED, 1999.

Recebido em 27/02/2014 Aceito para publicação em 25/07/2014 